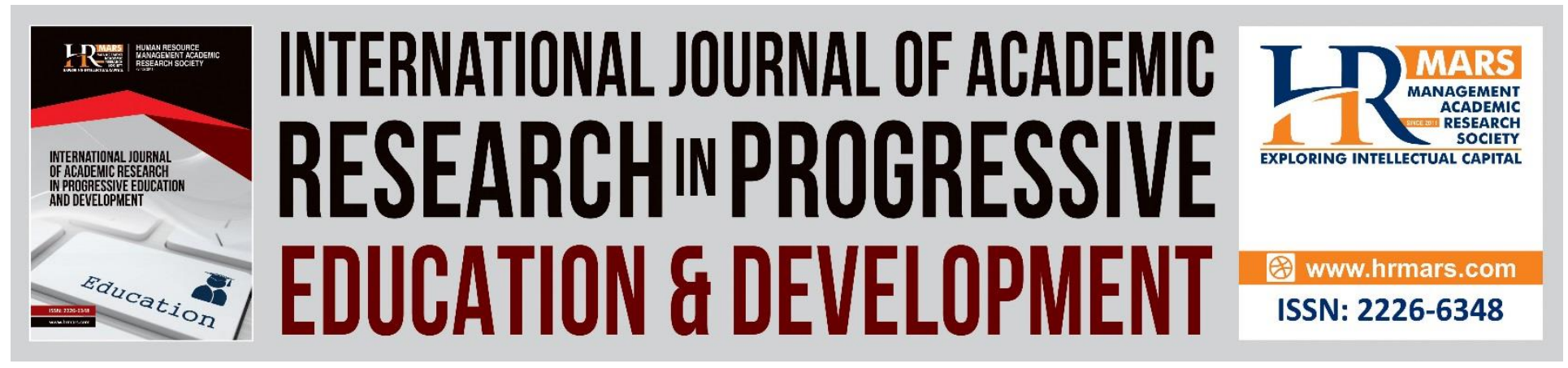

\title{
Approaches and Strategies to Learn and Improve Writing APA Style
}

Saiful Farik Mat Yatin, Suhana Mokhtar, Norsuzana Baharuddin and Nurhayati Ali

To Link this Article: http://dx.doi.org/10.6007/IJARPED/v7-i3/4348

DOI: $10.6007 /$ IJARPED/v7-i3/4348

Received: 03 June 2018, Revised: 18 June 2018, Accepted: 03 July 2018

Published Online: 20 July 2018

In-Text Citation: (Yatin, Mokhtar, Baharuddin, \& Ali, 2018)

To Cite this Article: Yatin, S. F. M., Mokhtar, S., Baharuddin, N., \& Ali, N. (2018). Approaches and Strategies to Learn and Improve Writing APA Style. International Journal of Academic Research in Progressive Education and Development, 7(3), 74-85.

\section{Copyright: (c) 2018 The Author(s)}

Published by Human Resource Management Academic Research Society (www.hrmars.com)

This article is published under the Creative Commons Attribution (CC BY 4.0) license. Anyone may reproduce, distribute, translate and create derivative works of this article (for both commercial and non-commercial purposes), subject to full attribution to the original publication and authors. The full terms of this license may be seen

at: http://creativecommons.org/licences/by/4.0/legalcode

Vol. 7, No. 3, July 2018, Pg. 74 - 85

Full Terms \& Conditions of access and use can be found at http://hrmars.com/index.php/pages/detail/publication-ethics 


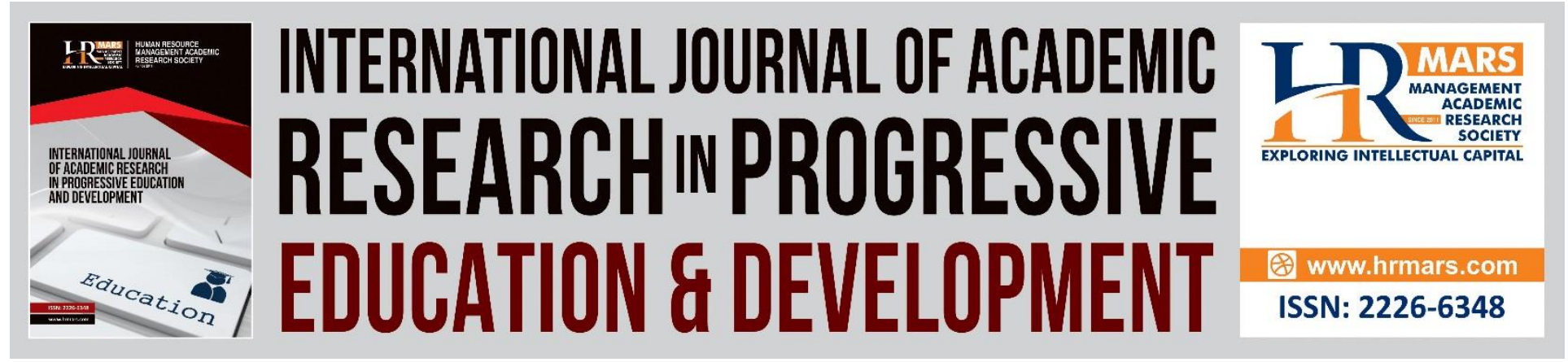

\title{
Approaches and Strategies to Learn and Improve Writing APA Style
}

\section{Saiful Farik Mat Yatin, Suhana Mokhtar, Norsuzana Baharuddin and Nurhayati Ali}

Faculty of Information Management, Puncak Perdana Campus, Universiti Teknologi MARA

(UiTM Selangor), Malaysia.

\begin{abstract}
APA (American Psychological Association) is the most well known and used to cite sources within the behavioral and social sciences. Therefore, students often struggle to write in APA Style and they commonly made errors and mistakes. Besides that, both instructors and students having problems to teach and learn APA Style. Due to that, the objective of this study is to discovered the learning patterns in order to find approaches and strategies to learn APA Style, address the main areas of concern with problematic in student writing and present most common grammatical APA errors made by authors. The quantitative methods where multiple cases study approach is adopted; three articles were selected in order to support this study. One of the significant findings is the learning pattern from task performances analysis. The paper discusses the issues related to the problem in writing with APA Style. The paper's findings and discovery are significant in highlighting approaches and strategies, which needed to be addressed to emphasize student writing with APA style in order to avoid common APA Style mistakes made by students when write and publish manuscript.
\end{abstract}

Keywords: APA Style, American Psychological Association, Documentation Style, Writing Skills, Information Management

\section{Introduction}

APA stands for American Psychological Association where this association establishes APA as a style guide that contains set of guidelines and rules intended to encourage and maintain clear, concise writing in psychology and related fields such as psychology, anthropology, sociology, as well as education and other fields. APA Style guidelines assure clarity, uniformity and credibility of publish manuscript. These guidelines are set down of formats and rules in the Publication Manual of APA Style. According to APA (2010), "it concerns uniform use of such elements in APA Style like selection of headings, tone, and length; punctuation and abbreviations; presentation of numbers and statistics; construction of tables and figures, citation of references; and many other elements in APA Style that are a part of a manuscript". APA Style documentation helps to prevent 


\title{
INTERNATIONAL JOURNAL OF ACADEMIC RESEARCH IN PROGRESSIVE EDUCATION AND
} DEVELOPMENT

Vol. 7, No. 3, July 2018, E-ISSN: 2226-6348 @ 2018 HRMARS

circumstance of stealing other people intellectual property and maintain the acquisition of integrity and honesty especially when writes a research paper for academic and professional purposes. The academic integrity and honesty are substantial for research papers, where the result or findings are based on methodology used. Any term or word that is copy directly from original sources when writing a manuscript must be properly cited to avoid plagiarism. APA guidelines address the important to credit sources where all the information taken from the source must be properly cite in citation or in references. As a result, manuscript will be more credible. The main objective of APA style is to facilitate scientific communication by promoting clarity of expression and by standardizing the organization and content of a manuscript. APA guidelines also help to present the manuscript in familiar and expected ways.

\section{The History}

The APA was founded at the end of the nineteenth century with only 31 original group members where the inception of the group members was part of a movement of emerging academic disciplines, including psychology, economics, physiology, political science, and biochemistry. As the membership growth, APA today is the largest association of psychologists in the world.

The Publication Manual officially established in 1929 as a short journal article that provided simple set of procedures, or style rules, that would codify the many components of scientific writing to increase the ease of reading comprehension. During this time, professionalization was a priority for psychology, both in the spirit of industry popular in that time period, as well as the boom in the field of psychology. Psychology journals of the time were suddenly required to sort through much more material than they had previously, and a standardization of psychological writing helped bring order and professional legitimacy to a rapidly growing field. It was later expanded and published as a book by the association and is now in its sixth edition (APA, 2010). It was released in July 2009 after four years of development. APA Publication manual consist of eight section or chapter (see Figure 1) and each chapter clearly explains the formats and guideline to write in APA Style.

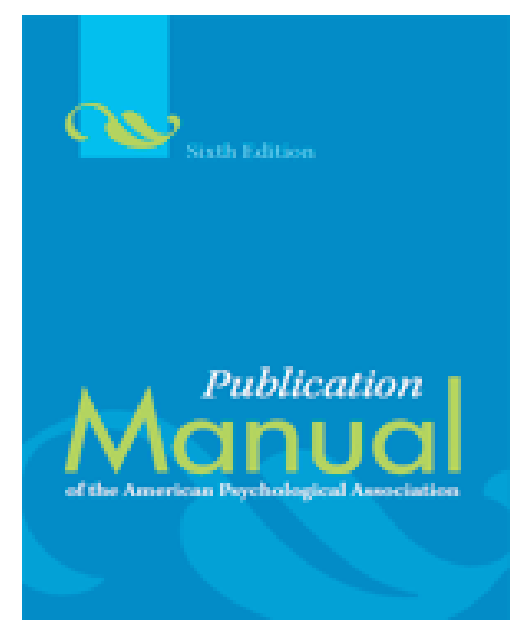

\author{
Chapter 1: Writing for the Behavioral and Social Sciences \\ Chapter 2: Manuscript Structure and Content \\ Chapter 3: Writing Clearly and Concisely \\ Chapter 4: The Mechanics of Style \\ Chapter 5: Displaying Results \\ Chapter 6: Crediting Sources \\ Chapter 7: Reference Examples \\ Chapter 8: The Publication Process
}

Figure 1: Publication Manual of the American Psychological Association, $6^{\text {th }}$.ed. In APA Style there are four major sections: The Title Page, Abstract, Main Body, and References (see Figure 2). A properly formatted abstract, which is a precise summary of the research 
Vol. 7, No. 3, July 2018, E-ISSN: 2226-6348 @ 2018 HRMARS

conducted, will give the reader an idea of what will come in the body of the paper. A reference page will allow the reader to further investigate the research presented.

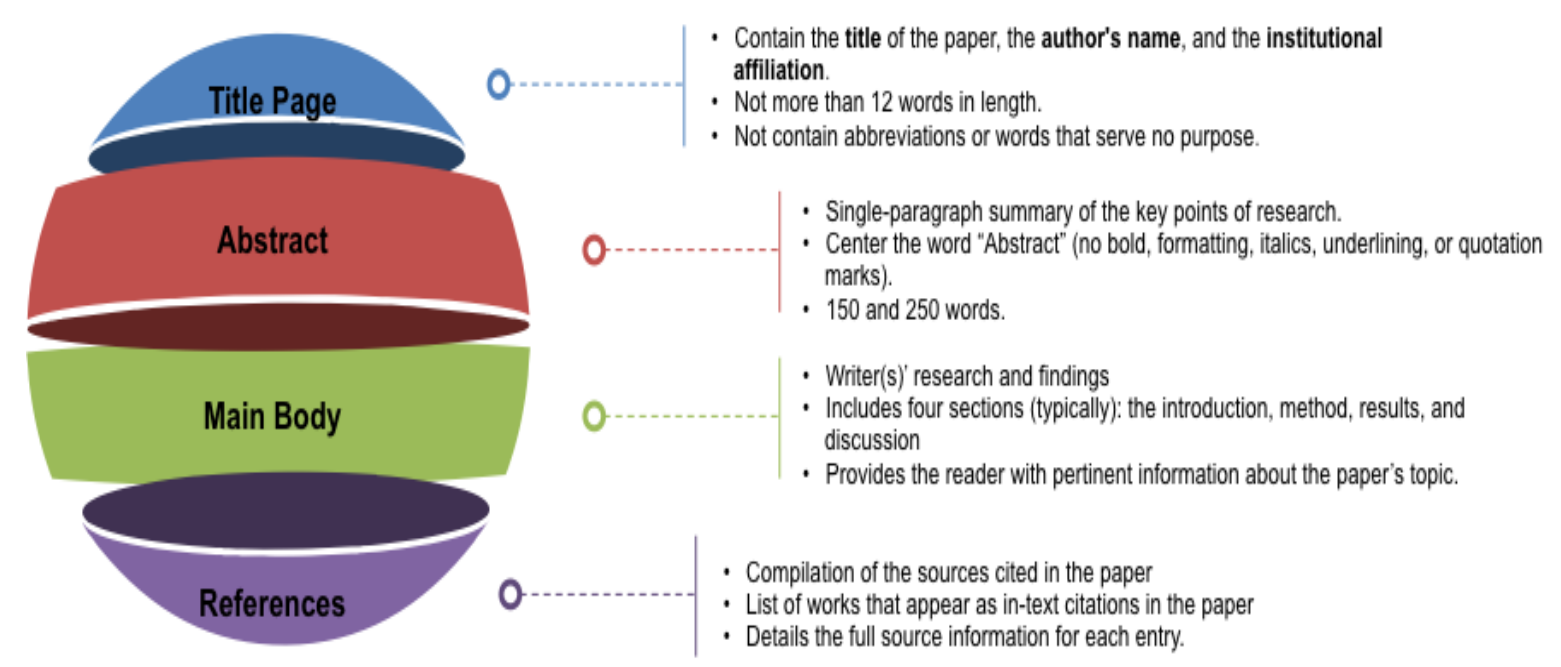

Figure 2: Four Major Sections of APA Style

Aside from the major sections, APA style also allows writers to use internal section dividers called headings to help organize the essay material. Depending on the length and complexity of the manuscript, there could be up to five levels of headings. Students are needed to follow general APA guidelines, formats and citation in order to deliver quality writing when they were instructed to write and publish a manuscript.

\section{Problem Statement}

Documentation formats like APA become the "language" for students who want to write appropriately and deliver a quality manuscript. However, due to the lack of understanding APA style and writing skills, students often struggle to write in APA style and commonly made mistakes. Meanwhile, instructors have problem on how the best to help them master APA style.

\section{Learning Patterns (Lack of Writing Skills)}

They commonly make mistakes and didn't realize the importance of writing with discipline especially when write a manuscript for academic purposes. Chism and Weerakoon (2012) relates the problems with the nature and behavior of students when learn something new especially for the first-time learner, they tend to overlook the content of their article due to lack of writing skills. There are too many rules and format to follows and students often made some errors when write a manuscript.

\section{Problematic in Writing}

Recent study by Onwuegbuzie (2017) he analyzed 117 sample submitted to journal repository of Research of the School (RITS) to find the most common grammatical APA errors committed. As a result, he identified 35 most frequent formal grammatical errors in the manuscripts. This is the result from poor APA writing skills. Through this study, it shows most of the authors unable to 


\section{INTERNATIONAL JOURNAL OF ACADEMIC RESEARCH IN PROGRESSIVE EDUCATION AND}

DEVELOPMENT

Vol. 7, No. 3, July 2018, E-ISSN: 2226-6348 @ 2018 HRMARS

understand APA style. When write with documentation style like APA is actually quite easy and look like straightforward task where all the formats and guideline already stated in APA Publication Manual, but students are fail to follow it. There are many factors influenced students writing style. According to Chism and Weerakoon (2012) students' lack of strategies for locating APA information. They complained that they are not enough examples and relied on Google to find APA information and locate sample citation. Chism and Weerakoon (2012) also found that students make assumption all journals they found in Google Scholar, ERIC or EBSCO were using $A P A$. They tend to use it as a sample to write manuscript. To avoid this situation, it is very important for instructor to provide such information they need and improve their teaching skills in order to make students understand well in APA Style. To do that, Shermis, Burstein and Leacock (2006) address the important of using computer as tool to assist in the evaluation of writing. Meanwhile, Pajares and Valiante (2006) relate the student's characteristics and behavior that influence their writing skills.

\section{Citation Errors}

Mandernach, Zafonte and Taylor (2016) focused their study on the use of APA Style. In their study, they asked instructors to comments 50 sample papers to locate errors in APA formatting and most of the error was citation errors. Citation is important parts in APA Style where it stresses the importance to give credit and cite the original sources, which acknowledge others' ideas and research that have been used in paper. Without cite the original source in paper, it will be considered as a plagiarism.

\section{A Need for Practice}

"Practice make perfect". This is common statement that's shows the need of practice in order to master any field of study. This also means that exercise plays an important role to present critical aspect and improve writing skills when using APA Style. The study of exercise is shown in Fallahi et al., (2006) paper. Based on their study, improvement in student writing only can be seen from the fourth exercise. This indicates that by practice a lot to master APA may helps to build selfefficiency in writing.

\section{Student's conceptualization}

Student often cannot develop their conceptualization in writing because not guided by the goals and objectives. Suitable model to develop student's conceptualization are crucial elements to achieve the goals and objective. By using task force selected model can be use to coordinate and plan strategies in teaching, learning and evaluation of writing APA.

\section{Objectives}

This paper attempts to:

- Discovered the learning patterns in order to find approaches and strategies to learn APA Style.

- Address the main areas of concern with problematic in student writing.

- Identify the most common APA citation errors made by authors. 


\section{Literature Review}

Academic writing is a designed style of writing that need to use in this newest era. To produce a good piece of work, it's essential for students to use an academic documentation style. One of the documentation styles is APA Style. APA Style created a collection of rules in citation and formatting for scholarly writing to ensure a professional standard of academic integrity. Writing in style is accounted as a complex process for students. Instructor has greatest challenges to assist students and they need strategies in order to help students master with APA Style. Previous study by Mandernach, Zafonte and Taylor (2016) were state four teaching strategies to help instructor and students. By employing classroom assessment techniques can help students to understand techniques in writing with style.

\section{Student's Learning Patterns.}

By making connection with students learning pattern through observation and experience will helps to learn about the characteristic and behavior of students. A learning pattern is a comprehensible about the learning activities where beliefs and motivation of students are related. As for learning strategies, the trend among students is to make enquiries and address their concerns through various online resources (Chism and Weerakoon, 2012). As a result, there is growing interest in including more skills instruction across the curriculum, particularly in research-and writing-intensive courses (Elmborg and Hook, 2005).

The task of learning and applying proper APA style is not an easy task. The difficulty students have when learning APA has been discovered by numerous studies. According to Ault (1991), "Writing APA-style journal articles or research reports is a complicated task for undergraduates, because they are creating and organizing the prose while trying to follow format conventions" (p. 45). Students usually make effort to apply the knowledge of how to write the text of a research paper in addition to following the citation format; many times, this causes errors in both the text and citations of the paper. Franz and Spitzer (2006) note, "students often express frustration with formatting a manuscript according to predetermined guidelines, which can become the focus of their efforts and undermine the quality of their prose" (p. 13). Because most students are unfamiliar with APA format, their first attempt at using the style many times results in a paper that is lacking in both content and form.

Students often use online resources as a reference to learn APA Style. Online resources provide lots of information about APA Style including the guidelines and format, sample APA paper, examples of APA citation and etc. As an instructor, they can use this medium to develop blogs to engage with students. Blogs contain APA Style information will help students to understand it betters. Besides that, by list trusted website where students can find information about APA Style easily. Sometimes students didn't know either information provided by certain website about APA Style is correct or not. Chism and Weerakoon (2012) agree and found "practice seemed to improve performance, showing that familiarity and attentiveness to the task were important success factors. A key recognition, however, was that while performance on some APA style citation tasks seem to improve with practice, others require explicit repeated modeling of 
INTERNATIONAL JOURNAL OF ACADEMIC RESEARCH IN PROGRESSIVE EDUCATION AND DEVELOPMENT

Vol. 7, No. 3, July 2018, E-ISSN: 2226-6348 @ 2018 HRMARS

elements that seem quirky, complicated, or contradictory to prior experience, which take longer to master" (p. 35)

Student characteristics one of the factors contributes towards their learning patterns. Most of students tend to learn from doing. Task performance analysis can be one of effective way to teach students. By provide sample APA papers that contain APA error can help students to identify the error. Learning from doing and learning from mistakes can help students to emphasize their writing skills. This also can motivate students to apply work-checking behavior when writing with style.

\section{Student's Writing.}

Lack of understanding to APA Style will influenced their writing skills. Better understanding comes from better technique. Direct instruction in APA along with resource and practice seem to be most impactful. By implementing workshop in scientific writing helped students gain efficiency with APA Style. It will give significant effect in student writing. The ability to write is clearly one method by which students can demonstrate habits of mind and critical thinking skills. Writing ability can serve as an index of other cognitive functions, so it should be no surprise that writing ability may serve as a proxy measure for thinking like a psychologist or measuring a psychological 'habit of mind'. For example, Furnham (2010) concluded on the basis of a series of studies that proofreading for errors and omissions is positively correlated with verbal reasoning; specifically, the measures of general knowledge and vocabulary within the framework of crystallized intelligence.

\section{Common APA Citation Errors.}

As stated by the authors of APA (2010), "Incorrect grammar and careless construction of sentences distract the reader, introduce ambiguity and generally communication" (p. 77). From the statement, it is very important for students to write with discipline by avoid APA errors. To deliver quality manuscript, grammatical errors, APA Style errors and citation errors are the error committed by authors mostly. It can be seen from recent studied (Onwuegbuzie, 2017; Mandernach, Zafonte and Taylor (2016). The inability to properly cite using APA format was noted in doctoral students as well. Chism and Weerakoon (2012) conducted a study because they were so surprised by the mistakes found in their graduate students' APA papers. They write, "Puzzled by the poor performance of talented students on a routine exercise involving correcting bibliographic citations, we undertook a study of the reasons for these challenges" (Chism \& Weerakoon, 2012, p. 27). The authors were surprised the students were having difficulties because it was ruled out their errors were due to the factors of laziness or motivation on the part of the students (Chism and Weerakoon, 2012). These articles show APA difficulty is a common problem, but they also agree it is possible to learn the conventions of the style.

\section{Findings and Recommendations}

From the study that has been made about APA, we acknowledge that many students lack of publishable writing skills especially when writing with APA style and often fail to develop these skills. Writing skills are crucial element in order to deliver a quality manuscript. Meanwhile instructors are having problem to give lesson and guide students in writing with APA Style 
Vol. 7, No. 3, July 2018, E-ISSN: 2226-6348 @ 2018 HRMARS

effectively. Beside that, lack of knowledge about APA contributes to the poor writing of manuscript. Student usually didn't learn from mistake and didn't plan their time properly to complete their manuscript. These 'last minute' habits will affect their writing performances and the quality of their manuscript. Time management is important to avoid this bad habit. The manuscript tends to be rejected when the quality of their manuscript is not meet the standard that has been stated in the Publication Manual. In response to these findings, several effective solutions are point out as follows:

\section{Professional Peer-Review Process}

Student can get benefit from professional peer review where this process involved with professional who can helps to find out any lack or weaknesses with the writing. It also can support them in enhancing and emphasize their writing skills and also learning process. The objective of peer review process is to evaluate the genuineness, value, quality and often the originality of manuscript for publication. Professional reviewers with specialized knowledge in certain field of study can help to review the manuscript by pinpoint areas for improvement and provide suggestions. As such, Wiley.com provides professional peer-review where it will give feedback based on professional review and critic.

\section{Internet Resources}

By getting relevant and correct information about APA Style can provide them knowledge to write with discipline for publishing a good and quality manuscript. The Publication Manual itself is the first choice to find resource about APA Style. However, alternatively students also can benefit from Internet resources to find any information about APA Style rather than look into the Publication Manual. Many good websites excellently present the basics and details of APA Style. For example, sample APA sheet by Purdue's OWL can be one of the best approaches to learn APA Style. Purdue's OWL provides free access and resources about APA Style and the information is updated like APA Publication Manual $6^{\text {th }}$ Edition (2010). The sample APA paper can be use as a template to write a proper manuscript. At the same time, this can be a beginning tool and reference for students especially for those who are started to familiar with APA formatting and citation style. Once they have the basic, it is recommended to refer and look into APA manual itself to revise and review the writing in accordance to other elements like bias in language, and references. Beside that, students can refer APA Style blog to get to know in depth about APA Style. APA Style blog also provide online community platform to discuss about any topic that student found the most challenging part. Through this blog, APA Style experts will answer each question about APA and provide guideline regarding APA. This blog not only answer the question ask by online community but also provide online tutorial and sample APA where can be use as a reference to write a quality manuscript.

\section{APA Errors Checklist}

Checklist provided represents the most common APA errors. By familiar with APA errors will help students to avoid APA violation. This checklist may help to identify and determine which formats and citation are needed in order to publish a quality manuscript. It also can help students to draw extra attention to the most challenging part in APA. Paper formatting, citation, references, bias of language, grammar and spelling are the aspects that are needed by student to take a look 
Vol. 7, No. 3, July 2018, E-ISSN: 2226-6348 @ 2018 HRMARS

when review their manuscript with the checklist. There are numbers of APA errors found by numerous studies. By referring to the previous studies about APA errors may help student to emphasize their writing skills.

\section{Develop Writing Skills}

Besides that, to emphasize students writing in APA Style, it is very important to develop writing skills from classroom assessment techniques. By employing this class, instructors can rate students' performances and find out students' weakness. Any part of APA Style that students having problem can be found and instructor can assist students how to correct it. By correct the errors and provide a guideline about the important rules and format on student papers may help them to take seriously about their mistakes. Student may pay attention to avoid APA violation in the future. As a result, it can develop writing skills and reduce number of error or mistakes made by students.

\section{Active Participant by Instructor}

Active participant by instructor can help authors especially students to deliver a quality manuscript. By provide university style guide internally can address majority of student writing questions. Students also can attend workshop handle by university and instructor to explain about the guidelines. An effective workshop depends on the quality of the APA learning objectives where it depends on the quality of the instructor. A well-designed workshop does not make an effective workshop. A weak instructor who is dependent on slides and lecture will deliver a weak teaching and learning APA Style. Strong instructors with a deep knowledge of the APA Style, an understanding of how the best to teach APA Style can deliver an effective workshop. This can increase proficiency in identifying APA Style as crucial element to publish a quality manuscript. By involve both instructor and student with various class lesson techniques and strategies can help them to teach and learn APA Style effectively. However, it is not easy for students to understand it. A conscientious instructor should be engaged in ongoing professional development, seeking to implement new techniques and strategies to try to improve student performance in writing especially when writing with style.

Highlight the Importance of APA

Furthermore, educational institute and instructor can highlight the used, roles and the importance of writing skills of APA in academic writing by figure out the correlation between APA and provide numerous resources to check out the added value in learning APA. By using APA Style to write a research paper, it provides readers with indication about the topic that author's ideas discuss in the paper effectively. Standard format from APA allows readers to easily concentrate on the ideas discuss rather being distracted by unfamiliar text and formats used. Hence, it helps establish the credibility of writing paper. The APA format clarifies each section and how to write sentences in order to express the ideas. The accuracy and concision are vital part for expressing the content or idea of manuscript. It helps to provide sufficient and useful information to readers who use the paper as a main reference to perform their task or better understanding in any topic. 
INTERNATIONAL JOURNAL OF ACADEMIC RESEARCH IN PROGRESSIVE EDUCATION AND DEVELOPMENT

Vol. 7, No. 3, July 2018, E-ISSN: 2226-6348 @ 2018 HRMARS

Require Special Attention by Instructor

The finding indicated that all students with difficulties learning APA Style require special attention by instructor. These students have special educational needs where they need a good instructor to help them. Instructor must develop different ways to present information in a manner and adapt their lessons to the needs of students. By provide assistance to students who require special attention through tutorial can helps students to understand in APA Style and emphasize their writing skills. Thus, instructor is the key player in order to help student master in APA where the development of APA learning starts from an effective teaching from instructor. Instructor must aware their student behavior and pay attention to student who are struggle to learn APA. Through special attention, it will create bond between instructor and student and at the same time will increase student motivation to learn APA in depth.

\section{Citation Machine}

Numerous studies have been made by researcher to find most common APA error. From that, it proved that one of common APA error is citation. Citation machine is a tool that provides service to generate citation and references. The accurate citation and references are generated based on format of documentation style. Like APA, there are lots of citation machine can be used through online. For example, Citationmachine.net helps students and professional to create citation to the original sources. Beside use of citation machine available online, software like EndNote also provide the same function. The use of citation machine may help to cite properly according to the format that has been stated in the Publication Manual.

\section{Conclusion}

In conclusion, mastering APA influenced by the way students learnt it. Better understanding came from approaches and strategies to master APA Style. Style sheet can be medium for helping students. Students who struggle with APA Style can use all these studies to improve their writing style. Thus, teaching APA format will most likely mean teaching it periodically from a variety of angles, so as to engage students and get them thinking about it periodically, thus providing them with opportunities to rely on previous experiences as they enhance their skills. It is useful to study about APA errors. The errors found can be used as guidelines and checklist to emphasize the writing style. This guidelines and checklist can give overview with the details that comprise APA format or the pattern of thought one must follow.

\section{References}

American Psychological Association. (2010). Publication manual of the American Psychological Association ( $6^{\text {th }}$. ed.). Washington, DC: Author.

American Psychological Association. (n.d.). APA history and archives. Retrieved December 27, 2017, from http://www.apa.org/about/apa/archives/apa-history.aspx

Ault, R. L. (1991, February). What goes where? An activity to teach the organization of journal articles. Teaching of Psychology, 18(1), 45. 
INTERNATIONAL JOURNAL OF ACADEMIC RESEARCH IN PROGRESSIVE EDUCATION AND

DEVELOPMENT

Vol. 7, No. 3, July 2018, E-ISSN: 2226-6348 @ 2018 HRMARS

Bentley, M., Peerenboom, C. A., Hodge, F. W., Passano, E. B., Warren, H. C., \& Washburn, M. F. (1929). Instructions in regard to preparation of manuscript. Psychological Bulletin, 26, 5763.

Covill, A. E. (2010). Comparing Peer Review and Self-Review as Ways to Improve College Students' Writing. Journal of Literacy Research. 42, 199-226.

Franz, T.M., \& Spitzer, T.M. (2006). Different approaches to teaching the mechanics of American Psychological Association style. Journal of Scholarship of Teaching and Learning, 6(2), 1320

Hoffman, N., Beatty, S., Feng, P., Lee, J. (2017). Teaching research skills through embedded librarianship. Reference Services Review, Vol. 45(2). 211-226.

Landrum, R. E. (2013). Writing in APA Style: faculty perspectives of competence and importance. Psychology Learning and Teaching. Vol. 12 (3), 259-265.

Mandernach, B. Jean, Z. M. \& Taylor, C. (2016). Instructional Strategies to Improve College Students' APA Style Writing. Journal of Teaching and Learning in Higher Education, Vol. 27(3), 407-412.

Onwuegbuzie, A. J. (2017). Most Common Formal Grammatical Errors Committed by Authors, Journal of Education Issues. Vol. 3(1), 109-140.

The OWL at Purdue. (2017). APA Formatting and Style Guide. Purdue University Online Writing Lab. Retrieved December 27, 2017, from http://owl.english.purdue.edu

Van Note Chism, N., \& Weerakoon, S. (2012). APA, Meet Google: Graduate students' approaches to learning citation style. Journal of the Scholarship of Teaching and Learning, Vol. 12(2), 27-38. 
INTERNATIONAL JOURNAL OF ACADEMIC RESEARCH IN PROGRESSIVE EDUCATION AND DEVELOPMENT

Vol. 7, No. 3, July 2018, E-ISSN: 2226-6348 @ 2018 HRMARS 